\title{
THE EFFECT OF SYNTHETIC GROWTH REGULATORS ON SELECTED PARAMETERS OF MEDICAGO X VARIA T. MARTYN AND TRIFOLIUM PRATENSE L. NUTRITIONAL VALUE
}

\author{
SOSNOWSKI, J.* - KRÓL, J. \\ Department of Grassland and Green Areas Creation, Siedlce University of Natural Sciences \\ and Humanities, Prusa 14 Street, 08-110 Siedlce, Poland \\ (phone: +48-25-643-1318) \\ *Corresponding author \\ e-mail: jacek.sosnowski@uph.edu.pl \\ (Received $23^{\text {rd }}$ Jul 2018; accepted $28^{\text {th }}$ Sep 2018)
}

\begin{abstract}
The aim of the paper is to study the effects of auxin and cytokinin, synthetic growth regulators, on selected parameters of hybrid alfalfa and red clover nutritional value. The experiment was conducted at the experimental facility of Siedlce University of Natural Sciences and Humanities between 2014 and 2016. In the autumn of 2014 plastic cylinders with no bottom, $40 \mathrm{~cm}$ high and with the diameter of $36 \mathrm{~cm}$, were sunk $30 \mathrm{~cm}$ deep into the ground, with spacing of $0.8 \times 0.8 \mathrm{~m}$. They were filled with the soil of the anthropogenic order. Experimental factors: plant species - hybrid alfalfa and red clover, growth regulator - control (distilled water), indole-3-butric acid (auxin), 6-benzyloaminopuryn (cytokinin), indole-3-butric acid + 6-benzylaminopuryn. After plants in each cylinder were harvested their chemical analysis was carried out. Dry matter digestibility (\%) and total protein, crude fibre concentration in dry matter $\left(\mathrm{g} \mathrm{kg}^{-1}\right)$ was determined with the NIRS method using the Buchi NIRFlex N-500 spectrometer. The results of the multi-factor experiment with 24 experimental units were processed statistically using repeated measures analysis of variance. Growth regulators affected the content of protein and crude fibre in plant matter in different wayes. Cytokinin and a mixture of hormones reduced the concentration of protein relative to the control, but fibre share increased. Auxin had no significant effect on these features. Keywords: auxin, cytokinin, Fabaceae, total protein, crude fibre, dry mater digestibility
\end{abstract}

\section{Introduction}

Auxin and cytokinin are important plant hormones regulating such important physiological processes as nutrient transport (Jenik and Barton, 2005). Additionally, according to many authors (Jenik and Barton, 2005; Cheng et al., 2006, 2007; Weijers et al., 2006), natural plant hormones take part in root elongation, which, in turn, affects the rate of nutrient absorption from the soil. It was confirmed by other studies that plant growth regulators containing synthetic hormones stimulate root system growth too, increasing nutrient uptake form the soil (Hwang and Sakakibara, 2006). Ali et al. (2008) reported that auxins are leading factors in this process, acting as signals informing about the state of physiological processes in cells and about growing demand for nutrients, this way attracting them. Thus, high quantities of soil nutrients are absorbed by the roots, and big amounts of them are transported from vegetative to generative parts.

According to Nowak and Wróbel $(2010 \mathrm{a}, \mathrm{b})$ chemicals and mineral fertilizers can no longer be used in rising quantities to increase agricultural productivity, which is why there is a need to look for other substances affecting plant growth. The authors' opinion is that such growth regulators should increase production potential in unfavourable climatic and in other adverse conditions, not conducive to the growth and development of a particular plant species. Von Richthofen (2006) pointed out that those products would be very important in the case of Fabaceae plants, with their unstable growth and 
sensitivity to weather conditions. Among growth regulators there are synthetic plant hormones that have been used both in agriculture and horticulture for quite a few years (Czapla et al., 2005; Nowak and Wróbel, 2010a, b; Wierzbowska and Bowszys, 2008)

For economic and environmental reasons Fabacea plants like lucerne (Medicago x varia T. Martyn) and clover (Trifolium pratense L.) are worth considering for cultivation in larger areas. Those plants make it possible to limit mineral fertiliser use, and, besides, they contribute to activation and movement of many nutrients in the soil (Wilczek et al., 2006). Additionally, Fabaceae plants grown together with grass species as mixtures improve physical and chemical properties of the soil, positively affecting its structure, fertility, biological activity of microflora, and movement of nutrients from lower to upper layers (Gaweł and Żurek, 2003). Wild growing clover (Trifolium pratense L.) has been known for a long time, mainly as a medicinal plant (Booth et al., 2006). High content of polyphenols and isoflavones belonging to the group of phytoestrogens such as daidzein, genistein, formononetin and biochanin makes it an antioxidant plant (Surh et al., 2006). Present in Fabaceae plants Polyphenol compounds positively affect human health, for example, mitigating menopause symptoms, preventing development of cardiovascular disease, and lowering a risk of some cancer forms (Thompson et al., 2007). High-protein PX (protein-xanthophyll) concentrate is an alfalfa product which may become widely used in animal nutrition, while EFL (extract fleur lucerne) produced form concentrated alfalfa juice is used in human nutrition. For their yield to be high and to contain high protein content, plants used to produce PX should be grown in good conditions, without weeds. All chemical treatments should be applied according to the withdrawal period, to maintain high standards of health and safety (Plaza et al., 2003; Karwowska et al., 2010). Both of the above substances are produced by extracting proteins, macronutrients, and vitamins from alfalfa juice, with indigestible elements removed earlier (Brito et al., 2007).

The aim of the paper is to study the effects of auxin and cytokinin, synthetic growth regulators, on selected parameters of Medicago x varia T. Martyn and Trifolium pratense $\mathrm{L}$. nutritional value. The purpose of the experiment was to assess the impact of indole-3-butyric acid (synthetic auxin), 6-benzyloaminopuryn (synthetic cytokinin), and their mixture on total protein and crude fibre content, and dry mater digestibility of selected plants.

\section{Material and methods}

\section{Experimental conditions}

The experiment was conducted at the experimental facility of Siedlce University of Natural Sciences and Humanities (52 ${ }^{\circ} 10^{\prime} 03^{\prime \prime} \mathrm{N}$; 22 ${ }^{\circ} 17^{\prime} 24$ 'E; Poland) between 2014 and 2016. In the autumn of 2014 plastic cylinders with no bottom, $40 \mathrm{~cm}$ high and with the diameter of $36 \mathrm{~cm}$, were sunk $30 \mathrm{~cm}$ deep into the ground, with spacing of $0.8 \times 0.8 \mathrm{~m}$. They were filled with the soil of the anthropogenic order, culture earth type, hortiolse subtype, and the granulometric composition of loamy sand. Before the experiment was set up, organic carbon $\left(\mathrm{C}_{\text {org }}\right)$ concentration in the soil was $13.50 \mathrm{~g} \mathrm{~kg}^{-1} \mathrm{DM}$, with total nitrogen concentration of $1.30 \mathrm{~g} \mathrm{~kg}^{-1} \mathrm{DM}$. The ratio of $\mathrm{C}: \mathrm{N}$ was $10.4: 1$, and soil $\mathrm{pH}$ of 6.8 was close to neutral. The soil had high content of phosphorus and magnesium, while available forms of potassium were of medium quantities. Because of relatively high content of nutrients mineral fertilizers were not used. 
Plastic sheeting was spread between the plants to prevent weeds from sprouting. Next, 10 seeds were planted into each cylinder. After germination, when seedlings had 3-10 leaves, three best looking plants were selected for further research, while the others were removed. In the growing seasons of 2015 and 2016 plants reached their full potential to be harvested three times when $30-40 \%$ alfalfa and clover plants were in the bloom stage. The experiment was set up in a split-plot design with three replications (Fig. 1).
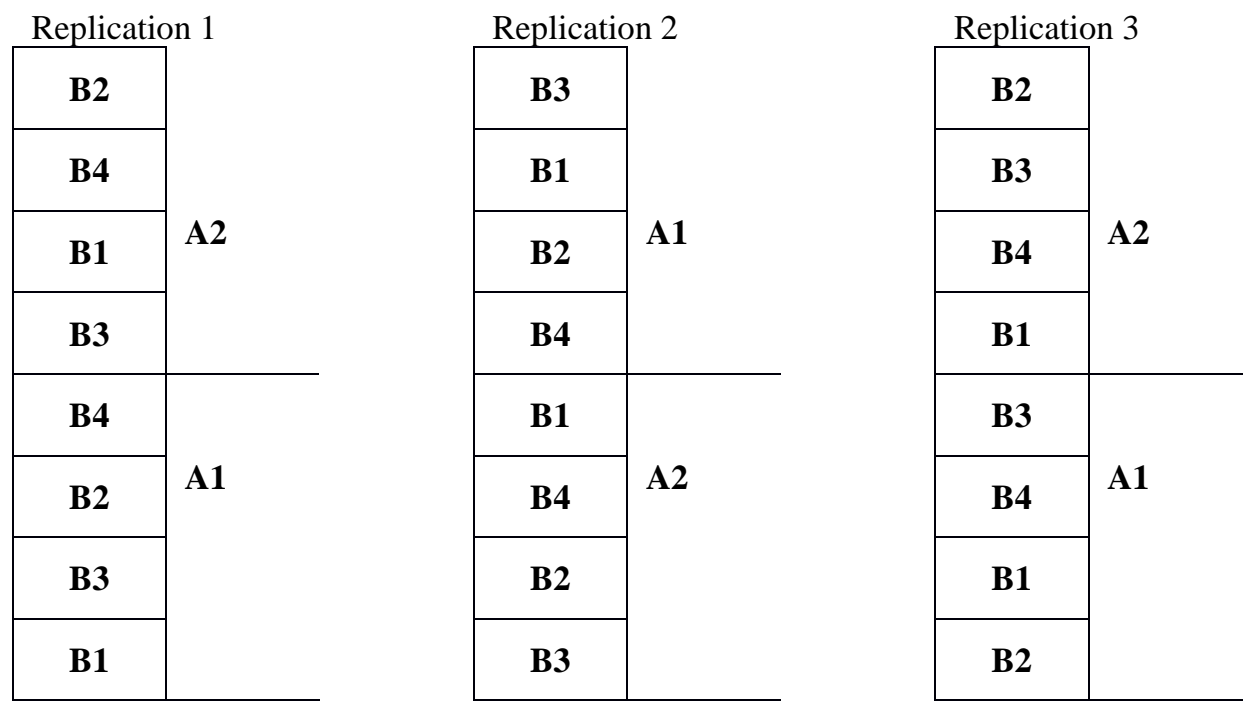

Figure 1. The outlay of the experiment. Plants: A1 - hybrid alfalfa, A2 - red clover. Treatments: B1 - control, B2 - auxin; B3 - cytokinin, B4 - auxin + cytokinin

Experimental factors:

- Plant species: hybrid alfalfa (Medicago x varia T. Martyn) var. Kometa and red clover (Trifolium pratense L.) var. Krynia;

- Growth regulator (applied as a spray): $\mathrm{K}$ - control (distilled water), A - indole3-butric acid (IBA - synthetic auxin), C - 6-benzyloaminopuryn (BAP synthetic cytokinin), AC - indole-3-butric acid + 6-benzylaminopuryn (IBA+BAP at a rate of 1:1).

Plants were treated twice during each growing cycle:

- Hybrid alfalfa - the first treatment after the development of the first internode, the other when the first flower buds were visible outside leaves;

- Red clover - the first treatment after the appearance of the first branches, the other when the first florescence emerged.

For the plants to be thoroughly covered, $0.2 \mathrm{dm}^{3}$ of spraying liquid was used per one cylinder with growth regulator concentration of $30 \mathrm{mg} \mathrm{dm}^{-3}$. The control unit was treated with the same amount of distilled water.

After plants in each cylinder were harvested their chemical analysis was carried out. Dry matter digestibility (\%) and total protein, crude fibre concentration in dry matter $\left(\mathrm{g} \mathrm{kg}^{-1}\right)$ was determined with the NIRS method using the Buchi NIRFlex N-500 spectrometer. 


\section{Weather conditions}

Sielianinov's hydrothermal coefficient was calculated in order to determine temporal variation of meteorological conditions and their effects on vegetation. The hydrothermal coefficient $(\mathrm{K})$ was calculated on the basis of monthly sums of precipitation $(\mathrm{P})$ and a sum of monthly air temperatures ( $\mathrm{t}$ ), using the following formula (Skowera and Puła, 2004):

\section{$\mathrm{K}=\mathrm{P} / 0.1 \sum t$}

Values of Selianinov's hydrothermal coefficient $(\mathrm{K})$ are presented in Table 1. It was assumed that extreme conditions took place when its value was below 0.7 and above 2.5 (Skowera and Puła, 2004).

Table 1. The value of Sielianinov's hydrothermal coefficient $(K)$ in the growing season

\begin{tabular}{c|c|c|c|c|c|c|c}
\hline \multirow{2}{*}{ Years } & \multicolumn{7}{|c}{ Months } \\
\cline { 2 - 8 } & April & May & June & July & August & September & October \\
\hline \multirow{2}{*}{2014} & 1.36 & 1.87 & 1.64 & 0.59 & 1.92 & 0.64 & 0.12 \\
& $(\mathrm{o})$ & $(\mathrm{mw})$ & $(\mathrm{mw})$ & $(\mathrm{sd})$ & $(\mathrm{mw})$ & $(\mathrm{sd})$ & $(\mathrm{ed})$ \\
& 1.22 & 2.63 & 0.87 & 1.08 & 0.18 & 1.46 & 1.94 \\
2015 & $(\mathrm{md})$ & $(\mathrm{sw})$ & $(\mathrm{d})$ & $(\mathrm{md})$ & $(\mathrm{ed})$ & $(\mathrm{o})$ & $(\mathrm{mw})$ \\
& 1.89 & 0.82 & 1.02 & 2.15 & 1.05 & 0.36 & 7.65 \\
& $(\mathrm{mw})$ & $(\mathrm{d})$ & $(\mathrm{md})$ & $(\mathrm{w})$ & $(\mathrm{md})$ & $(\mathrm{ed})$ & $(\mathrm{ew})$ \\
\hline
\end{tabular}

$\mathrm{K} \leq 0.4$ extreme drought (ed). $0.4<\mathrm{K} \leq 0.7$ severe drought (sd). $0.7<\mathrm{K} \leq 1.0$ drought (d). $1.0<\mathrm{K} \leq$ 1.3 moderate drought (md). $1.3<\mathrm{K} \leq 1.6$ optimal (o). $1.6<\mathrm{K} \leq 2.0$ moderately wet (mw). $2.0<\mathrm{K} \leq$ 2.5 wet (w). $2.5<\mathrm{K} \leq 3.0$ severely wet (sw). $\mathrm{K}>3.0$ extremely wet (ew)

2014 - the year in which the experiment was established, 2015 and 2016 - years of full use of experience

Optimal temperature and moisture conditions were only in April 2014 and in September 2015. In the remaining months of the growing periods they were not as favourable, varying from extremely dry in August 2015 to extremely wet in May 2014. Throughout the experiment the best conditions were at the beginning of each growing season. It can be concluded that the most difficult situation for plants was in 2015, when, apart from May and the end of the growing season, the weather ranged from moderately dry to extremely dry. The growing season of 2016 was characterized by a lack of a period with optimal conditions for plant growth. A high level of precipitation in July $(\mathrm{K}=2.15)$ and drought in most of the remaining months hindered proper growth and development of plants.

\section{Statistical analysis}

The results of the multi-factor experiment with 24 experimental units were processed statistically using repeated measures analysis of variance; the same forage parameters were measured during each growing cycle. The Fisher-Snedecor test was done to determine the significance of the effect of experimental factors on the parameters. Tukey's test was used to compare differences between means at the $\mathrm{LSD}_{0.05}$ significance level. All the calculations were made with the Statistica $13-2017$ program. In tables 
homogenous groups are marked with letters. Means in lines and columns marked with the same letters are not significantly different.

\section{Results and discussion}

Total protein concentration (Table 2), an average for treatments, was in a statistically significant way higher in hybrid alfalfa $\left(199 \mathrm{~g} \mathrm{~kg}^{-1}\right)$ than in red clover $\left(176 \mathrm{~g} \mathrm{~kg}^{-1}\right)$. The concentration in red clover was lower but at close levels during both growing seasons; similar results were recorded by Ćwintal and Kościelecka (2005) in their experiment on diploid and tetraploid red clover agricultural value. Throughout the experiment protein concentration was the highest in the second year, also in alfalfa, with $203 \mathrm{~g} \mathrm{~kg}^{-1}$.

Table 2. The effect of growth regulators on total protein concentration $\left(\mathrm{g} \mathrm{kg}^{-1} \mathrm{DM}\right)$

\begin{tabular}{|c|c|c|c|}
\hline \multirow{2}{*}{ Treatments } & \multicolumn{2}{|c|}{ Year } & \multirow{2}{*}{ Means } \\
\hline & 2015 & 2016 & \\
\hline \multicolumn{4}{|c|}{ Treatment effect } \\
\hline $\mathrm{K}$ & $194 \mathrm{Aa}$ & $185 \mathrm{Aa}$ & $189 \mathrm{a}$ \\
\hline $\mathrm{A}$ & $187 \mathrm{Aa}$ & $190 \mathrm{Aa}$ & 189 a \\
\hline $\mathrm{C}$ & $181 \mathrm{Ab}$ & $190 \mathrm{Aa}$ & $186 \mathrm{~b}$ \\
\hline $\mathrm{AC}$ & $185 \mathrm{Ab}$ & $187 \mathrm{Aa}$ & $186 \mathrm{~b}$ \\
\hline \multicolumn{4}{|c|}{ Species effect } \\
\hline Hybrid alfalfa & $195 \mathrm{Ba}$ & $203 \mathrm{Aa}$ & $199 \mathrm{a}$ \\
\hline Red clover & $179 \mathrm{Ab}$ & $173 \mathrm{Ab}$ & $176 \mathrm{~b}$ \\
\hline Means & $187 \mathrm{~A}$ & $188 \mathrm{~A}$ & \\
\hline
\end{tabular}

Means followed by the same lowercase letters in columns are not significantly different. Means followed by the same capital letters in lines are not significantly different.

$\mathrm{K}$ - control (distilled water), A - synthetic auxin, C - synthetic cytokinin, AC - synthetic auxin + synthetic cytokinin

Growth regulators diversified total protein concentration in dry matter. It was the highest in plants from units treated with auxin and from the control, with the identical value of $189 \mathrm{~g} \mathrm{~kg}^{-1}$. Cytokinin and a mixture of auxin with cytokinin resulted in statistically significant reductions of protein content in the biomass. Average annual protein content values were similar throughout the experiment, but there were some differences between harvests (see below). Gaweł and Żurek (2003) studying protein content in three varieties of alfalfa demonstrated opposite results, with its decrease in consecutive years. Low total protein content in the present experiment resulted from longer growing cycles, which was a consequence of three harvests instead of four. Andrzejewska et al. (2013) found that delaying alfalfa harvest time from the beginning of the flower budding stage to the flowering stage resulted in a decrease in protein content by, on average, $20 \mathrm{~g} \mathrm{~kg}^{-1}$. In addition, the authors discovered that this delay caused an increase in the amount of fibre.

In the present experiment there was some diversification of total protein content in plants caused by an interaction between the effect of a regulator and a harvest (Table 3). The highest average total protein content for both species was in the first harvest $\left(202 \mathrm{~g} \mathrm{~kg}^{-1}\right)$, and it was lower in the second $\left(188 \mathrm{~g} \mathrm{~kg}^{-1}\right)$ and third $\left(172 \mathrm{~g} \mathrm{~kg}^{-1}\right)$. 
Table 3. The effect of growth regulators on total protein concentration in harvests $\left(\mathrm{g} \mathrm{kg} \mathrm{g}^{-1}\right.$ $D M)$

\begin{tabular}{c|c|c|c}
\hline \multirow{2}{*}{ Treatments } & \multicolumn{3}{|c}{ Harvest } \\
\cline { 2 - 4 } & $\mathbf{1}$ & $\mathbf{2}$ & $\mathbf{3}$ \\
\hline \multicolumn{4}{c}{ Treatment effect } \\
\hline $\mathrm{K}$ & $212 \mathrm{Aa}$ & $187 \mathrm{Ba}$ & $170 \mathrm{Ca}$ \\
$\mathrm{A}$ & $199 \mathrm{Ab}$ & $195 \mathrm{Aa}$ & $173 \mathrm{Bc}$ \\
$\mathrm{C}$ & $201 \mathrm{Aab}$ & $188 \mathrm{Aab}$ & $167 \mathrm{Ba}$ \\
$\mathrm{AC}$ & $197 \mathrm{Ab}$ & $181 \mathrm{Ba}$ & $180 \mathrm{Ba}$ \\
\hline \multicolumn{4}{|}{} \\
\hline \multicolumn{4}{c}{ Species effect } \\
\hline Hybrid alfalfa & $214 \mathrm{Aa}$ & $198 \mathrm{Ba}$ & $185 \mathrm{Ca}$ \\
Red clover & $190 \mathrm{Ab}$ & $178 \mathrm{Bb}$ & $160 \mathrm{Cb}$ \\
Means & $202 \mathrm{~A}$ & $188 \mathrm{~B}$ & $172 \mathrm{C}$ \\
\hline
\end{tabular}

Means followed by the same lowercase letters in columns are not significantly different. Means followed by the same capital letters in lines are not significantly different

$\mathrm{K}$ - control (distilled water), A - synthetic auxin, C - synthetic cytokinin, AC - synthetic auxin + synthetic cytokinin

The above differences were statistically significant. Those findings were comparable with results provided by Wilczek et al. (2005a). Wilczek et al. (2005a, b) examined selected varieties of hybrid alfalfa and alfalfa (Medicago sativa L.) and found total protein content in those plants at the level of $170-220 \mathrm{~g} \mathrm{~kg}^{-1} \mathrm{DM}$. In turn, Stochmal et al. (2000) identified general protein content in legume plants as $190 \mathrm{~g} \mathrm{~kg}^{-1} \mathrm{DM}$.

Hybrid alfalfa had higher average concentration of crude fibre $\left(239 \mathrm{~g} \mathrm{~kg}^{-1}\right)$ than red clover (Table 4). This concentration in red clover was in a statistically significant way similar in both growing seasons $\left(2015-214 \mathrm{~g} \mathrm{~kg}^{-1} ; 2016-216 \mathrm{~g} \mathrm{~kg}^{-1}\right)$. Crude fibre content was diversified by growth regulators, and it was on average the highest in forage from units treated with cytokinin $\left(234 \mathrm{~g} \mathrm{~kg}^{-1}\right)$ and with a mixture of auxin and cytokinin $\left(231 \mathrm{~g} \mathrm{~kg}^{-1}\right)$. In the control unit and in the one with auxin there was statistically significant reduction of crude fibre concentration, by, on average, $5.1 \%$.

Table 4. The effect of growth regulators on crude fibre concentration $\left(g \mathrm{~kg}^{-1} \mathrm{DM}\right)$

\begin{tabular}{c|c|c|c}
\hline \multirow{2}{*}{ Treatments } & \multicolumn{2}{|c}{ Year } & \multirow{2}{*}{ Means } \\
\cline { 2 - 3 } & \multicolumn{2}{|c}{$\mathbf{2 0 1 5}$} & $\mathbf{2 0 1 6}$ \\
\hline \multicolumn{3}{c}{ Treatment effect } \\
$\mathrm{A}$ & $225 \mathrm{Ab}$ & $219 \mathrm{Ab}$ & $222 \mathrm{~b}$ \\
$\mathrm{C}$ & $219 \mathrm{Ab}$ & $221 \mathrm{Ab}$ & $220 \mathrm{~b}$ \\
$\mathrm{AC}$ & $237 \mathrm{Aa}$ & $231 \mathrm{Ba}$ & $234 \mathrm{a}$ \\
\hline \multicolumn{3}{|c}{ Species effect } & $231 \mathrm{a}$ \\
\hline Hybrid alfalfa & $243 \mathrm{Aa}$ & $235 \mathrm{Ba}$ & $239 \mathrm{a}$ \\
Red clover & $214 \mathrm{Ab}$ & $216 \mathrm{Ab}$ & $215 \mathrm{~b}$ \\
Means & $228 \mathrm{~A}$ & $225 \mathrm{~A}$ & \\
\hline
\end{tabular}

Means followed by the same lowercase letters in columns are not significantly different. Means followed by the same capital letters in lines are not significantly different

$\mathrm{K}$ - control (distilled water), A - synthetic auxin, C - synthetic cytokinin, AC - synthetic auxin + synthetic cytokinin 
As an average for both species crude fibre content underwent substantial variation as a result of regulator and harvest interaction (Table 5). In the first and second harvests auxin caused a statistically significant decline in fibre concentration, to 207 and $231 \mathrm{~g} \mathrm{~kg}^{-1}$. In the third harvest the regulator also caused a decrease, but this trend was not statistically significant. The experiment confirmed the view of differences in fibre content between consecutive harvests. Forage from the first and third harvests had a better nutritional value because fibre content was in a statistically significant way lower than in the second one. This tendency in consecutive harvests was confirmed by other authors (Wilczek et al., 2005a, b).

Table 5. The effect of growth regulators on crude fibre concentration in harvests ( $\left.\mathrm{kg}^{-1} \mathrm{DM}\right)$

\begin{tabular}{c|c|c|c}
\hline \multirow{2}{*}{ Treatments } & \multicolumn{3}{|c}{ Harvest } \\
\cline { 2 - 4 } & \multicolumn{4}{c}{$\mathbf{1}$} & $\mathbf{2}$ & $\mathbf{3}$ \\
\hline \multicolumn{4}{c}{ Treatment effect } \\
$\mathrm{K}$ & $221 \mathrm{ABa}$ & $235 \mathrm{Abc}$ & $210 \mathrm{Bb}$ \\
$\mathrm{A}$ & $207 \mathrm{Bb}$ & $231 \mathrm{Ac}$ & $223 \mathrm{Aab}$ \\
$\mathrm{AC}$ & $222 \mathrm{Ba}$ & $251 \mathrm{Aa}$ & $230 \mathrm{Ba}$ \\
\hline \multicolumn{4}{c}{ Species effect } \\
\hline Hybrid alfalfa & $225 \mathrm{Ba}$ & $261 \mathrm{Aa}$ & $230 \mathrm{Ba}$ \\
Red clover & $213 \mathrm{Aa}$ & $220 \mathrm{Ab}$ & $213 \mathrm{Ab}$ \\
Means & $219 \mathrm{~B}$ & $241 \mathrm{~A}$ & $221 \mathrm{~B}$ \\
\hline
\end{tabular}

Means followed by the same lowercase letters in columns are not significantly different. Means followed by the same capital letters in lines are not significantly different

K - control (distilled water), A - synthetic auxin, C - synthetic cytokinin, AC - synthetic auxin + synthetic cytokinin

According to Gaweł (2009) proper digestibility of plant material should be around $65 \%$. Dry matter digestibility (Table 6), i.e. percentage of nutrients absorbed by the digestive system, was significantly higher in red clover $(52.7 \%)$ than in alfalfa hybrid $(50.5 \%)$, with a statistically significantly increase in the latter plant in the second year. This result was confirmed by the research of Gawel (2012), when digestibility of alfalfa mixtures with grasses was also the highest in the second year.

Generally, throughout the research growth regulators did not affect red clover and hybrid alfalfa digestibility, with its average annual values remaining similar with no statistically significant differences. However, there were differences between harvests during the same growing season (Table 7). The lowest value, average for the species and the regulator, was in the biomass of the second harvest (48.2\%), while plant material from the first and third ones had statistically significantly higher digestibility, $53 \%$ and $53.6 \%$, respectively. The highest digestibility of all samples was in alfalfa treated with growth regulators in the third harvest (55.5\%), and the lowest in the second $(45.2 \%)$. In red clover dry-matter digestibility in the second and third harvests remained at a similar level and was significantly lower than the values in the first one.

According to Gaweł and Żurek (2003) the number of growing cycles in a growing season had a marked effect on plant digestibility. This was closely related to the development stage at the harvest time and the pace of plant senescence. Overall, low digestibility of hybrid alfalfa and red clover in the present study resulted from the three 
harvests in the growing season. Gawel $(2009,2012)$ reported that with four harvests read clover had dry matter digestibility of $72 \%$, and growing this species in a mixture of grasses raised it to $75 \%$.

Table 6. The effect of growth regulators on digestibility (\%)

\begin{tabular}{c|c|c|c}
\hline \multirow{2}{*}{ Treatments } & \multicolumn{2}{|c}{ Year } & \multirow{2}{*}{ Means } \\
\cline { 2 - 3 } & $\mathbf{2 0 1 5}$ & $\mathbf{2 0 1 6}$ & \\
\hline $\mathrm{K}$ & $52.0 \mathrm{Aa}$ & $53.2 \mathrm{Aa}$ & $52.6 \mathrm{a}$ \\
$\mathrm{A}$ & $51.6 \mathrm{Aa}$ & $51.5 \mathrm{Aa}$ & $51.5 \mathrm{a}$ \\
$\mathrm{C}$ & $49.9 \mathrm{Aa}$ & $51.9 \mathrm{Aa}$ & $50.9 \mathrm{a}$ \\
$\mathrm{AC}$ & $50.4 \mathrm{Aa}$ & $52.5 \mathrm{Ba}$ & $51.4 \mathrm{a}$ \\
\hline \multicolumn{3}{|}{} \\
\hline Treatment effect \\
Red clovecies effect & $49.8 \mathrm{Bb}$ & $51.2 \mathrm{Ab}$ & $50.5 \mathrm{~b}$ \\
Means & $52.1 \mathrm{Aa}$ & $53.3 \mathrm{Aa}$ & $52.7 \mathrm{a}$ \\
\hline
\end{tabular}

Means followed by the same lowercase letters in columns are not significantly different. Means followed by the same capital letters in lines are not significantly different

$\mathrm{K}$ - control (distilled water), A - synthetic auxin, C - synthetic cytokinin, AC - synthetic auxin + synthetic cytokinin

Table 7. The effect of growth regulators on digestibility of forage in individual harvests (\%)

\begin{tabular}{c|c|c|c}
\hline \multirow{2}{*}{ Treatments } & \multicolumn{3}{|c}{ Harvest } \\
\cline { 2 - 4 } & 1 & 2 & 3 \\
\hline \multicolumn{4}{c}{ Treatment effect } \\
$\mathrm{A}$ & $52.0 \mathrm{ABa}$ & $51.2 \mathrm{Ba}$ & $54.6 \mathrm{Aa}$ \\
$\mathrm{C}$ & $54.7 \mathrm{Aa}$ & $48.0 \mathrm{Bb}$ & $51.9 \mathrm{ABa}$ \\
$\mathrm{AC}$ & $52.1 \mathrm{Aa}$ & $47.2 \mathrm{Bb}$ & $53.4 \mathrm{Aa}$ \\
\hline \multicolumn{5}{c}{ Species effect } \\
\hline Hybrid alfalfa & $50.8 \mathrm{Bb}$ & $45.2 \mathrm{Cb}$ & $55.5 \mathrm{Aa}$ \\
Red clover & $55.2 \mathrm{Aa}$ & $51.2 \mathrm{Ba}$ & $51.6 \mathrm{Bb}$ \\
Means & $53.0 \mathrm{~A}$ & $48.2 \mathrm{~B}$ & $53.6 \mathrm{~A}$ \\
\hline
\end{tabular}

Means followed by the same lowercase letters in columns are not significantly different. Means followed by the same capital letters in lines are not significantly different

K - control (distilled water), A - synthetic auxin, C - synthetic cytokinin, AC - synthetic auxin + synthetic cytokinin

In the first harvest of the first and second years (Fig. 2) the highest dry matter digestibility was on units treated with auxin, but the values were not significantly higher than those obtained on units with other treatments.

In the second harvest of the second year (2016) it was highest on the control and on units with cytokinin. Other treatments decreased this value. In turn, in the third harvest of the second year the highest dry matter digestibility was on the unit treated with a mixture of auxin with cytokinin, and it was statistically significantly higher than the 
values on other units. It should be noted that that growing season was characterized by extreme weather conditions. September 2016 was extremely dry and October extremely wet (Table 1). Such a large diversity of weather conditions could have impacted the effect of hormone mixtures on plants. It can be concluded that because of the September drought in 2016 a mixture of auxin with cytokinin stimulated total protein accumulation in plants, limiting accumulation of fibrous substances. The consequence of this was a big increase in plant dry matter content. In turn, extremely wet October (monthly rainfall of $161.2 \mathrm{~mm}$ ) with low temperatures (daily average temperature of $7.2{ }^{\circ} \mathrm{C}$ ) slowed down accumulation of protein and of non-digestible substances.

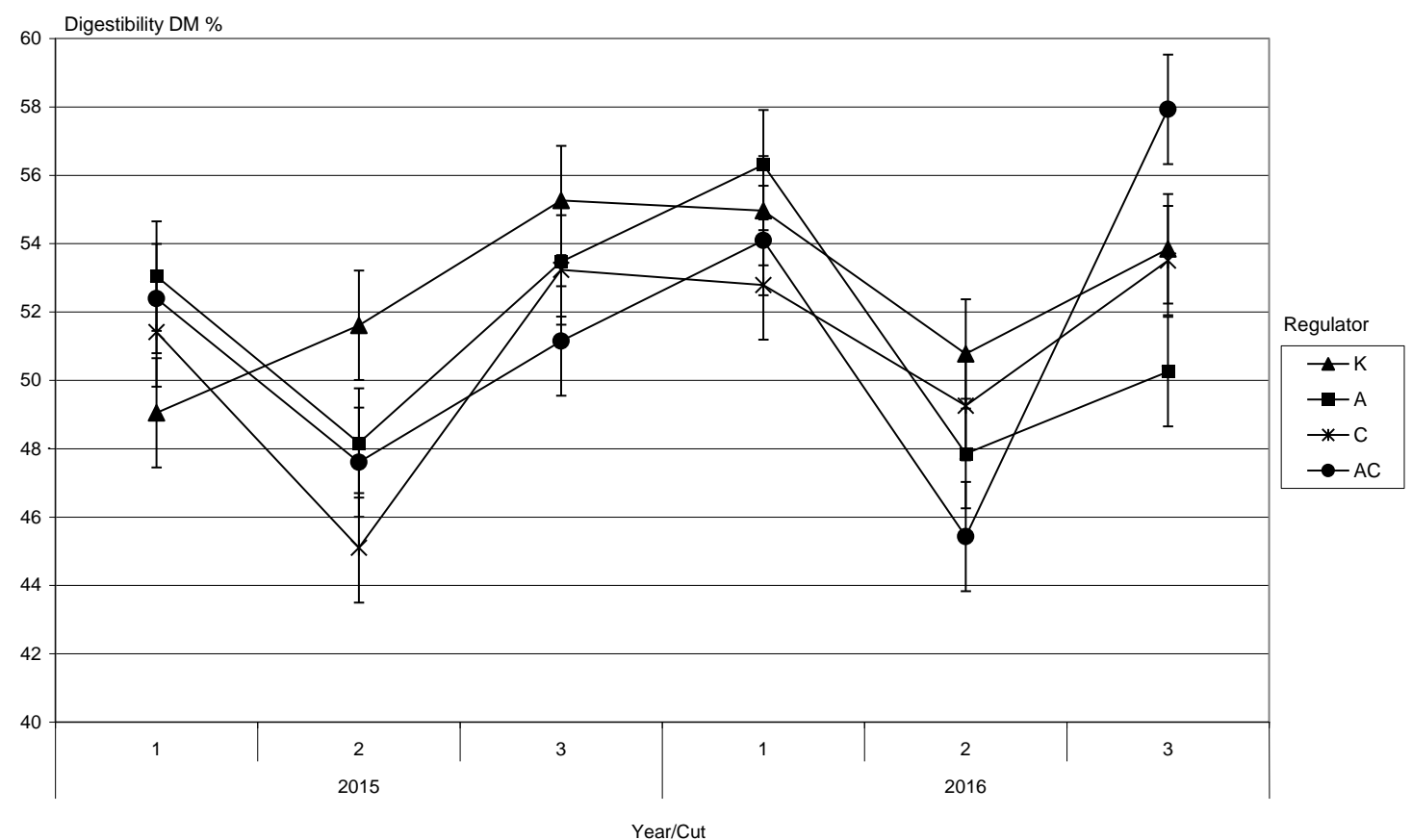

Figure 2. The effect of growth regulators on digestibility of forage in individual harvests (\%)

\section{Conclusions}

1. Exogenous growth regulators in different ways affected the content of protein and crude fibre in plant dry matter.

2. Cytokinin and a mixture of hormones reduced the concentration of protein relative to the control, but fibre share increased. Auxin had no significant effect on these features.

3. Overall, growth regulators did not change dry matter digestibility, but there were differences between harvests.

4. The experiment did not prove that the quality of plant material improved as a result of the application of synthetic auxin, cytokinin, and mixtures of these compounds.

Acknowledgements. The research carried out under the theme No 357/13/S was financed by the science grant of the Ministry of Science and Higher Education. 


\section{REFERENCES}

[1] Ali, B., Hayat, S., Hasan, S., Ahmad, A. (2008): A comparative effect of IAA and 4-ClIAA on growth, nodulation and nitrogen fixation in Vigna radiata (L.) - Acta Physiol. Plant. 30: 35-41.

[2] Andrzejewska, J., Albrecht, K. A., Jendrzejczak, E. (2013): Plant height and feed value of alfalfa in different development stages and cuts. - Fragm. Agron. 30(2): 14-22.

[3] Booth, N. L., Overk, C. R., Yao, P., Totura, S., Deng, Y., Hedayat, A. S., Bolton, J. L., Pauli, G. F., Farnsworth, R. (2006): Seasonal variation of red clover (Trifolium pratense L.) isoflavones and estrogenic activity. - J. Agric. Food Chem. 54: 1277-1282.

[4] Brito, A. F., Broderic, G. A, Olmos Colmenero, J. J., Reynal, S. (2007): Effects of feeding formatetreated alfalfa silage or red clover silage on omasal flow of nutrients and microbial protein synthesis in lactating dairy cows. - J. Dairy Sci. 90: 1392-1404.

[5] Cheng, Y., Dai, X., Zhao, Y. (2006): Auxin biosynthesis by the YUCCA Flavin monooxygenases controls the formation of floral organs and vascular tissues in Arabidopsis. - Genes \& Development 20: 1790-1799.

[6] Cheng, Y., Dai, X., Zhao, Y. (2007): Auxin synthesized by the YUCCA flavin monooxygenases is essential for embryogenesis and leaf formation in Arabidopsis. - The Plant Cell. 19: 2430-2439.

[7] Ćwintal, M., Kościelecka, D. (2005): The influence of the way of sowing and amount of seeds on the density structure, yielding and quality of diploid and tetraploid red clover in the year of sowing Part I. Density structure of plants and shoots. - Biul. IHAR 237/238: 237-248.

[8] Czapla, J., Stasiulewicz, L., Nogalska, A. (2005): Spring triticale yield as dependent upon growth regulators, applied alone or in combinations with magnesium sulphate - Acta Sci. Pol. Agricultura 4(2): 29-36.

[9] Gawel, E. (2009): Yielding of red clover and lucerne mixtures with grasses on the ecological farms. - J. Res. Appl. Agric. Eng. 54(3): 97-86.

[10] Gaweł, E. (2012): Nutritive value of lugume-grass mixtures cultivated in organic farms. J. Res. Appl. Agric. Eng. 57(3): 91-97.

[11] Gaweł, E., Żurek, J. (2003): Nutritional value of selected lucerne cultivars. - Biul. IHAR 225: 167-174.

[12] Hwang, I., Sakakibara, H. (2006): Cytokinin biosynthesis and perception. - Physiologia Plantarum 126: 528-538.

[13] Jenik, P. D., Barton, M. K. (2005): Surge and destroy: the role of auxin in plant embryogenesis. - Development 132: 3577-3585.

[14] Karwowska, M., Stadnik, J., Dolatowski, Z. J., Grela, R. E. (2010): Effect of proteinxanthophylls (PX) concentrate of alfalfa supplementation on physico-chemical properties of turkey breast and thigh muscles during ageing. - Meat Science 82(2): 486-490.

[15] Nowak, A., Wróbel, J. (2010a): The effect of growth regulators on content of assimilation pigment in leaves of three soybean cultivars (Glycine max L. Merr). - Rośliny OleisteOilseed Crops 31: 351-359.

[16] Nowak, A., Wróbel, J. (2010b): Impact of selected growth regulators on yielding of soybean (Glycine max L. Merr) in control requirements of substrate moisture. - Rośliny Oleiste-Oilseed Crops 31: 124-132.

[17] Plaza, L., De Ancos, B., Cano, M. P. (2003): Nutritional and health-related compounds in sprouts and seeds of soybean (Glycine max), wheat (Triticum aestivum. L) and alfalfa (Medicago sativa) treated by a new drying method. - Eur Food Res Technol. 216: 138144. DOI 10.1007/s00217-002-0640-9.

[18] Rylott, P. D., Smith, M. L. (1990): Effects of applied growth substances on pod set in broad beans (Vicia faba var. major). - J. Agri. Sci. 114: 41-47.

[19] Skowera, B., Puła, J. (2004): Pluviometric extreme conditions in spring season in Poland in the years 1971-2000. - Acta Agrophys. 3(1): 171-177. 


$$
-7043-
$$

[20] Stochmal, A., Simonet, A. M., Macias, F. A., Oliviera, M. A., Abreu, J. M., Nash, R., Oleszek, W. (2000): Acylated apigenin glycosides from alfalfa (Medicago sativa L.) var. Artal. - Phytochemistry 57: 1223-1226.

[21] Surh, J., Kim, M. J., Koh, E., Kim, Y-K. L., Kwon, H. (2006): Estimated intakes of isoflavones and coumestrol in Korean population. - Int. J. Food. Sci. Nutr. 57(5/6): 325344.

[22] Thompson, C. J., Pitter, M. H., Ernst, E. (2007): Trifolium pretense isoflavones in the treatment of menopausal hot flushes. - Phytomedicine 14: 153-159.

[23] Von Richthofen, J. S. (2006): What do European farmers think about grain legumes. Grain Legumes 45: 14-15.

[24] Weijers, D., Schlereth, A., Ehrismann, J. S., Schwank, G., Kientz, M., Jurgens, G. (2006): Auxin triggers transient local signaling for cell specification in Arabidopsis embryogenesis. - Dev. Cell. 10: 265-270.

[25] Wierzbowska, J., Bowszys, T. (2008): Effect of growth regulators applied together with different phosphorus fertilization levels on the content and accumulation of potassium, magnesium and calcium in spring wheat. - J. Elementol. 13(1): 411-422.

[26] Wilczek, M., Ćwintal, M., Kornas-Czuczwar, B., Koper, R. (2006): Influence of presowing laser stimulation and microelement nutrition $(\mathrm{B}, \mathrm{Mo})$ on yielding of seed of tetraploid red clover during four-year performance. - Acta Agrophys. 8(3): 735-743.

[27] Wilczek, M., Koper, R., Ćwintal, M., Korniłłowicz-Kowalska, T. (2005a): Germination capacity and health status of alfalfa seeds after laser treatment. - Int. Agrophysics 19(1): 85-89.

[28] Wilczek, M., Koper, R., Ćwintal, M., Korniłłowicz-Kowalska, T. (2005b): Germination capacity and health status of hybrid alfalfa seeds after laser treatment. - Int. Agrophysics 19(3): 257-261. 